\title{
Branch Lengths Do Not Indicate Support- Even in Maximum Likelihood
}

Accepted May 20, 2001

To the Editor:

It is still common to see the branch lengths of "phylograms"1 interpreted as indicating support for groups. This is unfortunate, for it is easy to find cases in which long branches do not indicate support and in fact create a highly misleading impression if so interpreted.

As a simple example, suppose that the data comprise four terminals A-D and 500 informative characters, of which half split the terminals $\mathrm{AB} / \mathrm{CD}$ and the rest $\mathrm{AC}$ / $B D$. The (undirected) consensus of most parsimonious trees is unresolved, so that the Bremer support (Bremer, 1988, 1994; cf. Farris, 1996) for either split is zero, but the internal branch of either tree has length 250 according to parsimonious optimization (Farris, 1970).

The same problem occurs with neighbor joining (NJ; Saitou and Nei, 1987). Using Kumar et al.'s (1993; cf. Farris and Källersjö, 1994) MEGA program, NJ gives the same two trees as parsimony (in this case, but see Farris et al., 1996), so that the consensus is unresolved, and there is no support for any grouping. Yet the interior branch of either tree has a $p$-distance length of 0.25 , corresponding to 125 substitutions. This difficulty also affects significance tests that are based on branch length. According to Rzhetsky and Nei's (1992) confidence probability (CP) test, both the NJ trees have a "highly significant" interior branch, with $\mathrm{CP}>99 \%$ !

This can even happen with branch-length tests in maximum-likelihood methods, as the example of Fig.

\footnotetext{
${ }^{1}$ Trees with branch lengths. The term was coined by pheneticist P. H. A. Sneath, apparently with the aim of making discussion of phylogenetic trees as cumbersome as possible (cf. Sneath, 1975).
}

1 illustrates. Only the first 16 sites of these data are shown; the full data comprise 60 copies of these, for a total of 960 sites. Using Felsenstein's (1993) dnaml program with default settings, ${ }^{2}$ this matrix has two different maximum-likelihood trees, as shown, with log-likelihood about -8106 . The consensus of these trees is unresolved, so that there is no support for any grouping. With the exception of the ABEF/CDGH split, however, all the interior branches of both trees have the same length, about 0.16 , and those lengths all have the same confidence internals, about 0.1265 to 0.188. According to Felsenstein's (1993) procedure, then, all of those splits are "highly significant" $(P<$ 0.01 ) - when in fact none of those splits has any support at all!

Such examples are not accidents, but reflect a fundamental flaw in tests based on branch length. All existing such tests are derived on the formal assumption that the tree topology is given (see Farris et al., 1999). What they actually test is the magnitude of the branch length, subject to that condition. But when, as in the examples here, the data leave doubt as to which tree is correct, tests of magnitude are not adequate to demonstrate support. As has been seen, a long and seemingly significant branch may occur even when the group is in fact entirely unsupported. Researchers who wish to assess support would be well advised to use methods that are more reliable in that application. These include consensus trees (Nixon and Carpenter,

\footnotetext{
${ }^{2}$ Empirical base frequencies, transition/transversion ratio $=2.0$, and one category of substitution rates. We found the multiple trees by inputting user trees. The program will not search for multiple trees itself.
} 


$\begin{array}{lll}\text { A } & \text { atcgacgt atcgacgt } \\ B & \text { atcgacgt tagcacgt } \\ C & \text { tagcacgt tacgcagt } \\ D & \text { tagcacgt tacgactg } \\ \text { E } & \text { tacgcagt atcgacgt } \\ \text { F } & \text { tacgcagt tagcacgt } \\ \text { G } & \text { tacgactg tacgcagt } \\ H & \text { tacgactg tacgactg }\end{array}$
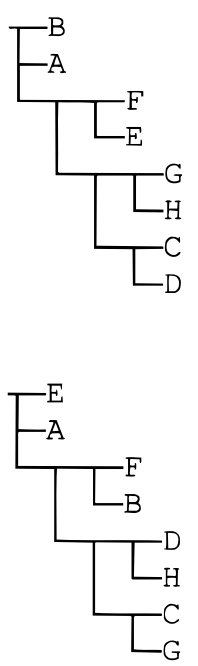

FIG. 1. A hypothetical matrix with two equally likely trees, as explained in the text.

1996; cf. Kluge, 1998; Judd, 1998; Carpenter et al., 1998), Bremer support (Bremer, 1994; cf. Lee, 1999), and resampling methods such as parsimony jackknifing (Farris et al., 1996; cf. Källersjö et al., 1999; Lipscomb et al., 1998).

\section{ACKNOWLEDGMENTS}

Preparation of this paper was supported by NFR Grant 10204 to J.S.F. We thank Dr. A. Anderberg for his support and encouragement. J.E.D.L. is a postdoctoral fellow of the F.W.O., the Fund for Scientific Research-Flanders (Belgium).

\section{REFERENCES}

Bremer, K. (1988). The limits of amino-acid sequence data in angiosperm phylogenetic reconstruction. Evolution 42, 795-803.

Bremer, K. (1994). Branch support and tree stability. Cladistics 10, 295-304.
Carpenter, J. M., Goloboff, P. A., and Farris, J. S. (1998). PTP is meaningless, T-PTP is contradictory: A reply to Trueman. Cladistics 14, 105-116.

Farris, J. S. (1970). Methods for computing Wagner Trees. Syst. Zool. 19, 83-92.

Farris, J. S. (1996). Names and origins. Cladistics 12, 263-264.

Farris, J. S., and Källersjö, M. (1994). Pro bono publico. Cladistics 10, 85-88.

Farris, J. S., Albert, V. A., Källersjö, M., Lipscomb, D. L., and Kluge, A. G. (1996). Parsimony jackknifing outperforms neighbor-joining. Cladistics 12, 99-124.

Farris, J. S., Källersjö, M., Crowe, T., Lipscomb, D., and Johansson, U. (1999). Frigatebirds, tropicbirds, and Ciconiida: Excesses of confidence probability. Cladistics 15, 1-7.

Felsenstein, J. (1993). PHYLIP, version 3.5c. Department of Genetics, University of Washington, Seattle.

Judd, D. D. (1998). Exploring component stability using life-stage concordance in sabethine mosquitoes (Diptera: Culicidae). Cladistics 14, 63-94.

Källersjö, M., Albert, V. A., and Farris, J. S. (1999). Homoplasy increases phylogenetic structure. Cladistics 15, 91-94.

Kluge, A. G. (1998). Total evidence or taxonomic congruence: Cladistics or consensus classification. Cladistics 14, 151-158.

Kumar, S., Tamura, K., and Nei, M. (1993). MEGA: Molecular Evolutionary Genetics Analysis, version 1.01, Computer software and documentation. Pennsylvania State University, University Park.

Lee, M. S. Y. (1999). Measuring support for phylogenies: The "proportional support index." Cladistics 15, 173-176.

Lipscomb, D. L., Farris, J. S., Källersjö, M., and Tehler, A. (1998). Support, ribosomal sequences, and the phylogeny of the eukaryotes. Cladistics 14, 303-338.

Nixon, K. C., and Carpenter, J. M. (1996). On consensus, collapsibility, and clade concordance. Cladistics 12, 305-322.

Rzhetsky, A., and Nei, M. (1992). A simple method for estimating and testing minimum-evolution trees. Mol. Biol. Evol. 9, 945-967.

Saitou, N., and Nei, M. (1987). The neighbor-joining method: A new method for reconstructing phylogenetic trees. Mol. Biol. Evol. 6, $514-525$.

Sneath, P. H. A. (1975). Cladistic representation of reticulate evolution. Syst. Zool. 24, 360-368.

James S. Farris*

Mari Källersjö*

Jan E. De Laet*, $\dagger$

*Molekylärsystematiska laboratoriet

Naturhistoriska riksmuseet,

Box 50007 SE 104-05 Stockholm, Sweden

$\dagger$ Laboratorium voor Systematiek

Instituut voor Plantkunde en Microbiologie

K.U. Leuven, Kard, Mercierlaan 92

B-3001 Leuven, Belgium 